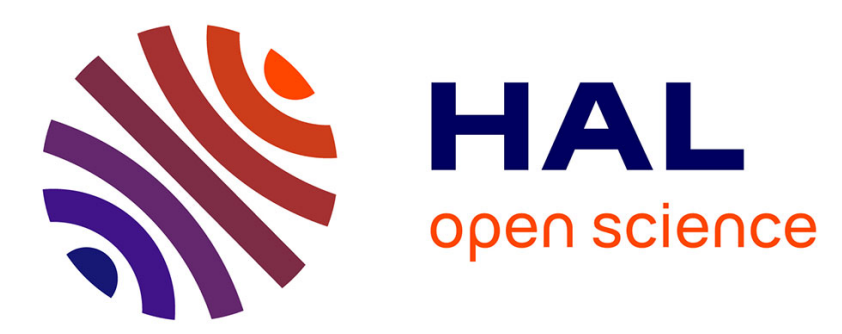

\title{
Introduction to the special section: Observations of the atmosphere of Mars with SPICAM spectrometers on board Mars Express
}

\author{
Jean-Loup Bertaux
}

\section{- To cite this version:}

Jean-Loup Bertaux. Introduction to the special section: Observations of the atmosphere of Mars with SPICAM spectrometers on board Mars Express. Journal of Geophysical Research. Planets, 2006, 111, pp.E09S01. 10.1029/2006JE002760 . hal-00095637

\section{HAL Id: hal-00095637 https://hal.science/hal-00095637}

Submitted on 12 Jan 2021

HAL is a multi-disciplinary open access archive for the deposit and dissemination of scientific research documents, whether they are published or not. The documents may come from teaching and research institutions in France or abroad, or from public or private research centers.
L'archive ouverte pluridisciplinaire HAL, est destinée au dépôt et à la diffusion de documents scientifiques de niveau recherche, publiés ou non, émanant des établissements d'enseignement et de recherche français ou étrangers, des laboratoires publics ou privés. 


\title{
Introduction to the special section: Observations of the atmosphere of Mars with SPICAM spectrometers on board Mars Express
}

\author{
Jean-Loup Bertaux ${ }^{1,2}$ \\ Received 31 May 2006; accepted 1 June 2006; published 13 September 2006.
}

Citation: Bertaux, J.-L. (2006), Introduction to the special section: Observations of the atmosphere of Mars with SPICAM spectrometers on board Mars Express, J. Geophys. Res., 111, E09S01, doi:10.1029/2006JE002760.

[1] This special section is a collection of papers describing some results of the SPICAM instrument on board Mars Express. Mars Express was inserted into orbit around Mars on 25 December 2003. It is the first autonomous planetary mission of the European Space Agency (ESA). One might wonder why it took so long for Europe to start exploring this most fascinating planet. The reasons are historical. After a long period of French-Soviet cooperation in space research managed by CNES, Roald Sagdeev, as Director of IKI (Space Research Institute in Moscow), opened cooperation more widely to other European countries providing instruments (as well as the USA). This new policy was initiated with the very successful VEGA 1 and VEGA 2 missions to Venus (1985) and the encounter with comet Halley in 1986. It was extended to the Phobos mission to Mars (half-successful) and to an ambitious mission to Mars, initially including penetrators and a balloon-borne camera of Jacques Blamont. It was the Mars 92 mission, which slipped to 1994, and then to 1996. Unfortunately, the failure of the fourth stage of the Proton launcher put an end to this ambitious Mars 96 spacecraft in November 1996. The whole European scientific community interested in Mars was involved in Mars 96, and for this reason ESA had not put Mars on its own agenda.

[2] Thanks to the efforts of Roger Bonnet (Director of Science at ESA) and his Deputy for Solar System Programmes, Marcello Coradini, a new mission was decided shortly after the failure of Mars 96 and developed in a record-breaking schedule: Mars Express, inaugurating the so-called "flexible" mission concept: fast development, standardized spacecraft, and more direct interface between
PI institutes and the spacecraft contractor (Astrium, for Mars Express). All instruments on Mars Express are reflights of their Mars 96 mission version, except SPICAM, the optical concept of which was modified to reduce enormously the mass of the instrument versus its Mars 96 version. SPICAM (SPectroscopie pour l'Investigation des Caractéristiques de l'Atmosphère de Mars) is a small dual UV-near-IR spectrometer, dedicated mainly to the atmosphere of Mars, and built by institutes of France, Belgium, and Russia.

[3] One global objective of Mars studies is to find if life exists now or ever existed on Mars. Clearly, SPICAM will not answer this question but more modestly will help to describe in detail the present atmospheric environment on Mars, addressing the present "habitability" of the planet. In addition, it will help to validate models describing the general circulation and the chemistry of the atmosphere. Once validated, these models may be used to compute important parameters which cannot be directly measured, or they may be used to simulate past conditions on Mars.

[4] SPICAM would possibly not exist without Vassili Ivanovitch Moroz, the great Russian planetary scientist, who promoted the exploration of Venus and Mars in the Soviet Union and was responsible of the Mars 96 mission. He passed away in 2004, but we will all remember his leading role in planetary space sciences and his scientific contribution to many aspects of the SPICAM science return.

J.-L. Bertaux, Université de Versailles Saint-Quentin-UVSQ, Service d' Aéronomie du CNRS/IPSL, BP 3, F-91371 Verrières-le-Buisson, France. (bertaux@aerov.jussieu.fr)

\footnotetext{
${ }^{1}$ Université de Versailles Saint-Quentin-UVSQ, Service d' Aéronomie du CNRS/IPSL, Verrières-le-Buisson, France.

${ }^{2}$ Université Pierre et Marie Curie-Paris 6, UMR 7620, Paris, France.

Copyright 2006 by the American Geophysical Union.

0148-0227/06/2006JE002760
} 